\title{
Pengaruh dosis pupuk hayati dan pupuk N, P, K terhadap komponen hasil dan hasil jagung (Zea mays L.) di dataran medium Jatinangor
}

\section{The influence of dosage biofertilizer and N, P, K fertilizer on yield component and yield maize (Zea mays L.) in medium land Jatinangor}

Diterima : 5 Juli 2018/Disetujui : 4 Agustus 2018 / Dipublikasikan : 7 Agustus 2018

CDepartment of Crop Science, Padjadjaran University

\begin{abstract}
The aim of the research was to study the influence of interaction and combination exactly between dosage of biofertilizer and N, P, $\mathrm{K}$ fertilizer on Growth and Yield Corn (Zea mays L.) P-12 Hibrid. The experiment at The Experimental Station in Jatinangor, Faculty of Agriculture, University of Padjadjaran, with an altitude of about 760 meter above sea level, soil type incepticols and type of climate D3 based on Oldeman method. The experimental design used was Randomized Block Design (RBD), factorial pattern using two factors and three replications. The first factor was $\mathrm{N}, \mathrm{P}, \mathrm{K}$ fertilizer Dosage $(\mathrm{K})$, consisted of three levels, $\mathrm{K} 1=100 \% \mathrm{~N}, \mathrm{P}, \mathrm{K}$ fertilizer, $\mathrm{K} 2=75 \% \mathrm{~N}, \mathrm{P}, \mathrm{K}$ fertilizer, and $\mathrm{K} 3=$ $50 \% \mathrm{~N}, \mathrm{P}, \mathrm{K}$ fertilizer. The second factor were biofertilizer dosage $(\mathrm{H})$, consisted of three levels, $\mathrm{h} 1=60 \mathrm{~kg} / \mathrm{ha}$ biofertilizer Petrobio, h2 $=90$ $\mathrm{kg} / \mathrm{ha}$ biofertilizer Petrobio, and h3 $=120 \mathrm{~kg} / \mathrm{ha}$ biofertilizer Petrobio. The result of this research indicates that there not were interaction between biofertilizer dosage with $\mathrm{N}, \mathrm{P}, \mathrm{K}$ fertilizer dosage to every observation parameter of growth and result of corn crop hibrida P-12 in medium plain Jatinangor. Single influence of treatment of biofertilizer h2 $(90 \mathrm{~kg} / \mathrm{ha})$ average of giving best influence to yield component and result of corn crop that is to cob diameter, number of seed lines per cob, number of seeds per cob, seed wight seed drought per cob and harvest index. Single influence of treatment of N, P, K fertilizer dose gives best influence of $\mathrm{k} 2(75 \% \mathrm{~N}, \mathrm{P}, \mathrm{K})$ to yield component and result att cob length, wight 100 seeds and wight seed drought per crop.
\end{abstract}

Keywords : Maize $\cdot$ Biofertilizer $\cdot$ N,P,K Fertilizer

\begin{tabular}{l}
\hline Dikomunikasikan oleh Ruminta \\
\hline${\text { Wahyudin, A. }{ }^{1} \cdot \text { F.Y. Wicaksono }}^{1} \cdot$ Irfan Maolana \\
1 Staf Pengajar Fakultas Pertanian Unpad \\
2 Alumni Fakultas Pertanian Unpad \\
Korespondensi:
\end{tabular}

Sari Penelitian ini bertujuan untuk mengetahui pengaruh interaksi dan kombinasi yang terbaik antara pemberian dosis pupuk hayati dan dosis pupuk N, P, K terhadap pertumbuhan dan hasil tanaman jagung hibrida P-12. Percobaan dilakukan di Kebun Percobaan Fakultas Pertanian Universitas Padjadjaran Jatinangor, dengan ketinggian 760 meter di atas permukaan laut, jenis tanah inseptisol dan tipe iklim C3 menurut Oldeman. Rancangan percobaan yang digunakan adalah Rancangan Acak Kelompok (RAK) pola faktorial dengan dua faktor perlakuan. Faktor pertama adalah dosis pupuk $\mathrm{N}, \mathrm{P}, \mathrm{K}$ yang terdiri dari tiga taraf yaitu $\mathrm{k} 1=100 \%$ pupuk $\mathrm{N}, \mathrm{P}, \mathrm{K}, \mathrm{k} 2=$ $75 \%$ pupuk N, $\mathrm{P}, \mathrm{K}$ dan $\mathrm{k} 3=50 \%$ pupuk $\mathrm{N}, \mathrm{P}, \mathrm{K}$. Faktor kedua adalah dosis pupuk hayati Petrobio $(\mathrm{H})$ yang terdiri dari tiga taraf, yaitu $\mathrm{h} 1=60 \mathrm{~kg} / \mathrm{ha}$ pupuk hayati Petrobio, h2 $=90 \mathrm{~kg} / \mathrm{ha}$ pupuk hayati Petrobio, dan h3 $=120 \mathrm{~kg} / \mathrm{ha}$ pupuk hayati Petrobio. Masing - masing kombinasi perlakuan diulang sebanyak tiga kali. Hasil penelitian menunjukkan bahwa tidak terdapat interaksi antara dosis pupuk hayati dan pupuk N, P, K terhadap setiap parameter pengamatan komponen hasil dan hasil tanaman jagung hibrida P-12 di dataran medium Jatinangor. Pengaruh mandiri perlakuan dosis pupuk hayati h2 $(90 \mathrm{~kg} / \mathrm{ha})$ rata rata memberikan pengaruh terbaik terhadap komponen hasil dan hasil tanaman jagung yaitu terhadap diameter tongkol, jumlah baris biji per tongkol, jumlah biji per tongkol, bobot biji pipilan kering per tanaman dan indeks panen, sedangkan pengaruh mandiri perlakuan dosis pupuk $\mathrm{N}, \mathrm{P}, \mathrm{K}$ k2 $(75 \% \mathrm{~N}, \mathrm{P}, \mathrm{K})$ memberikan pengaruh terbaik terhadap komponen hasil dan hasil yaitu pada panjang tongkol, bobot 100 biji dan bobot biji pipilan kering per tanaman.

Kata kunci : Jagung · Pupuk hayati · Pupuk N,P,K 


\section{Pendahuluan}

Tanaman jagung ( Zea mays L.) adalah tanaman serealia yang bernilai gizi cukup tinggi. Komposisi kimia biji jagung terdiri dari 74\% karbohidrat, 9\% protein, 4\% lemak dan kandungan lainnya, sehingga berpotensi sebagai sumber karbohidrat selain beras. Selain itu, tanaman jagung banyak digunakan sebagai pakan ternak karena hampir 50\% kandungan pakan ternak ayam berasal dari biji jagung (Anderson, 1979).

Di Indonesia, jagung merupakan tanaman pangan kedua setelah padi. Bahkan di beberapa daerah, jagung merupakan bahan makanan pokok utama pengganti beras atau sebagai campuran beras. Sekitar 70\% dari hasil produksi jagung digunakan untuk konsumsi. Selain sebagai bahan pangan, jagung juga menjadi campuran bahan pakan ternak, bahan ekspor nonmigas, serta bahan baku pendukung industri (Purwono dan Hartono, 2005).

Daerah penghasil utama tanaman jagung adalah Jawa Tengah, Jawa Barat, Jawa Timur, Madura, Daerah Istimewa Yogyakarta, Nusa Tenggara Timur, Sulawesi Selatan, Sulawesi Utara dan Madura. Khusus di daerah Jawa Timur dan Madura, tanaman jagung dibudidayakan cukup intensif karena selain tanah dan iklimnya sangat mendukung untuk pertumbuhan tanaman jagung, di daerah tersebut khususnya di Madura, jagung banyak dimanfaatkan sebagai makanan pokok (Warisno, 1998).

Salah satu upaya untuk meningkatkan produksi jagung dalam negeri yaitu melalui intensifikasi pertanian, dengan intensifikasi dapat dihasilkan produksi tanaman budidaya melalui peningkatan penambahan sarana produksi seoptimal mungkin untuk mendapatkan hasil tanaman yang maksimal pada luasan lahan pertanian tertentu (Gunawan Satari dkk., 2004).

Pupuk anorganik yang dibuat oleh pabrik-pabrik dengan meramu bahan-bahan kimia dengan kadar hara umumnya tinggi. Sebagai contoh ialah urea $(45 \%)$, TSP $(45 \%$ P2O5), ZA (20\% N), ZK (50\% K2O), SP-36 (36\% P2O5) dan lain sebagainya (Aisyah dkk., 2008). Pupuk anorganik merupakan salah satu teknologi budidaya yang berfungsi untuk menambah pasokan hara tanah serta menjaga dan meningkatkan kesuburan kimia tanah. Pupuk anorganik, seperti pupuk N, P, K, mudah diaplikasikan oleh petani pada areal pertanamannya (Mengel dan Kirkby, 1984).

Pupuk buatan berdasarkan bentuk, warna, dan cara penggunaan serta pemberiannya juga beranekaragam, ada yang diberikan melalui tanah, daun, dan lain sebagainya. Keuntungan menggunakan pupuk buatan yaitu dapat diberikan dengan takaran yang tepat sehingga kebutuhan hara oleh tanaman dapat dipenuhi dengan perbandingan yang tepat, tersedia dalam jumlah yang cukup, mudah diangkut karena relatif lebih sedikit bila dibandingkan dengan pupuk alam atau pupuk organik. Walaupun demikian, perlu diperhatikan bahwa pupuk buatan umumnya mengandung unsur hara makro, sehingga perlu digunakan pula pupuk hara mikro seperti pupuk kandang, kompos, pupuk hijau dan lain sebagainya (Aisyah dkk., 2008).

Pemupukan merupakan salah satu komponen teknologi yang masih memegang peranan penting dalam meningkatkan produktivitas tanaman, namun pemupukan yang dilakukan umumnya belum berimbang. Pemakaian pupuk anorganik secara intensif serta penggunaan bahan organik yang terabaikan untuk mengejar hasil yang tinggi merupakan salah satu penyebab menurunnya kandungan bahan organik tanah. Menurut Las dkk., (2002) keadaan ini dapat menyebabkan produktivitas menurun.

Usahan untuk mengatasi hal tersebut dapat dilakukan melalui pemupukan yang berimbang dan mengadopsi sistem pengolahan hara secara terpadu, termasuk penggunaan bahan organik (Adiningsih dkk., 1997). Pemupukan yang efektif dan efisien selain akan meningkatkan kualitas tanaman, juga dapat menjaga produktivitas dari tanah itu sendiri.

Pupuk hayati merupakan suatu bahan yang mengandung mikroorganisme bermanfaat untuk meningkatkan kesuburan tanah dan kualitas hasil tanaman, melalui peningkatan aktivitas biologi yang akhirnya dapat berinteraksi dengan sifat-sifat fisik dan kimia media tumbuh. Mikroorganisme yang umum digunakan sebagai bahan aktif pupuk hayati ialah mikroba penambat nitrogen, pelarut fosfat, dan pemantap agregat tanah (Rao, 1982).

Pupuk hayati dalam pengertian sempit adalah inokulan mikroba hidup, dimana mikroba dimasukkan ke dalam tanah untuk meningkatkan pengambilan hara oleh tanaman dari dalam tanah atau udara. Keuntungan 
diperoleh oleh keduanya yaitu, tanaman mendapatkan tambahan unsur hara yang diperlukan, sedangkan mikroba mendapatkan bahan organik untuk aktivitas dan pertumbuhannya (Handayani dkk., 1996).

Oleh karena itu, perlu dilakukan penelitian mengenai Pengaruh Dosis Pupuk Hayati dan Dosis Pupuk N, P, K terhadap Komponen Pertumbuhan dan Hasil Jagung Hibrida P-12 di dataran medium Jatinangor.

\section{Bahan dan Metode}

Penelitian dilakukan di kebun percobaan, Fakultas Pertanian Universitas Padjadjaran, pada ketinggian sekitar $750 \mathrm{~m}$ di atas permukaan laut dengan jenis tanah inceptisol. Tipe curah hujan di tempat percobaan adalah C3 menurut perhitungan Oldeman (1975). Bahanbahan yang digunakan dalam penelitian ini adalah : Benih Jagung Hibrida P-12, pupuk hayati Petrobio sebanyak $60 \mathrm{~kg} / \mathrm{ha}, 90 \mathrm{~kg} / \mathrm{ha}$, $120 \mathrm{~kg} / \mathrm{ha}$, pupuk urea $300 \mathrm{~kg} / \mathrm{ha}$, SP-18 400kg/ha, KCl $100 \mathrm{~kg} / \mathrm{ha}$ dan peptisida curacron 500 EC dan Dithane M-45 80 WP dengan konsentrasi masing - masing $2 \mathrm{ml} / \mathrm{L}$.

Percobaan ini menggunakan metode penelitian eksperimental, berbentuk Rancangan Acak Kelompok dengan pola faktorial. Perlakuan terdiri dari dua faktor dan masing-masing faktor terdiri dari tiga taraf. Adapun susunan faktor dan tarafnya adalah sebagai berikut. Faktor pertama adalah pupuk hayati Petrobio $(\mathrm{H})$ dengan 3 taraf : h1 $=60 \mathrm{~kg} / \mathrm{ha}, \mathrm{h} 2=90$ $\mathrm{kg} / \mathrm{ha}, \mathrm{h} 3=120 \mathrm{~kg} / \mathrm{ha}$ dan faktor kedua adalah dosis pupuk $\mathrm{N}, \mathrm{P}, \mathrm{K}(\mathrm{K})$ dengan 3 taraf : $\mathrm{k} 1=$ $100 \% \mathrm{~N}, \mathrm{P}, \mathrm{K}, \mathrm{k} 2=75 \% \mathrm{~N}, \mathrm{P}, \mathrm{K}$, dan $\mathrm{k} 3=50 \% \mathrm{~N}$, $\mathrm{P}, \mathrm{K}$. Dengan demikian terdapat $3 \times 3$ kombinasi perlakuan. Setiap perlakuan diulang tiga kali sehingga terdapat 27 plot percobaan. Ukuran petak percobaan adalah $3 \mathrm{~m} \times 2 \mathrm{~m}$ dengan kerapatan populasi 40 tanaman per petak.

Pengamatan meliputi : panjang tongkol $(\mathrm{cm})$, diameter tongkol $(\mathrm{cm})$, jumlah biji per tongkol, jumlah baris biji per tongkol, bobot 100 biji (g), bobot biji pipilan kering per tanaman (g) dan indeks panen (IP).

\section{Hasil dan Pembahasan}

Analisis sidik ragam menunjukkan bahwa tidak terjadi interaksi antara dosis pupuk $\mathrm{N}, \mathrm{P}, \mathrm{K}$ dengan dosis pupuk hayati terhadap panjang tongkol, diameter tongkol, jumlah baris biji per tongkol, jumlah biji per tongkol, bobot biji per tanaman, bobot 100 biji, dan indeks panen. Pengaruh secara mandiri dosis pupuk hayati dan N, P, K serta hasil uji jarak berganda Duncan pada taraf $5 \%$ terdapat pada tabel 1,2,3, dan 4.

Tabel 1. Pengaruh mandiri dosis pupuk hayati dan $\mathbf{N}, \mathbf{P}, \mathrm{K}$ terhadap panjang dan diameter tongkol jagung.

\begin{tabular}{lcc}
\hline \multicolumn{1}{c}{ Perlakuan } & $\begin{array}{c}\text { Panjang } \\
\text { Tongkol }(\mathrm{cm})\end{array}$ & $\begin{array}{c}\text { Diameter } \\
\text { Tongkol }(\mathrm{cm})\end{array}$ \\
\hline Dosis Pupuk Hayati & & \\
h1 $(60 \mathrm{~kg} / \mathrm{ha})$ & $13,60 \mathrm{a}$ & $3,92 \mathrm{ab}$ \\
h2 $(90 \mathrm{~kg} / \mathrm{ha})$ & $14,26 \mathrm{a}$ & $4,00 \mathrm{~b}$ \\
h3 $(120 \mathrm{~kg} / \mathrm{ha})$ & $13,43 \mathrm{a}$ & $3,74 \mathrm{a}$ \\
Dosis Pupuk Kimia & & \\
k1 $(100 \% \mathrm{~N}, \mathrm{P}, \mathrm{K})$ & $14,38 \mathrm{~b}$ & $3,97 \mathrm{a}$ \\
k2 $(75 \% \mathrm{~N}, \mathrm{P}, \mathrm{K})$ & $13,85 \mathrm{ab}$ & $3,92 \mathrm{a}$ \\
k3 $(50 \% \mathrm{~N}, \mathrm{P}, \mathrm{K})$ & $13,07 \mathrm{a}$ & $3,77 \mathrm{a}$ \\
\hline
\end{tabular}

Keterangan : Nilai rata-rata perlakuan yang ditandai dengan huruf yang sama pada kolom yang sama tidak berbeda nyata berdasarkan uji Jarak Berganda Duncan pada taraf nyata 5\%

Dari tabel 1 dapat dilihat bahwa pengaruh mandiri dosis pupuk hayati tidak menunjukkan perbedaan pada tiap perlakuannya terhadap panjang tongkol jagung, namun pada pupuk $\mathrm{N}$, $\mathrm{P}, \mathrm{K}$ menunjukkan adanya perbedaan pada tiap perlakuannya terhadap panjang tongkol jagung, yaitu perlakuan $\mathrm{k} 1(100 \% \mathrm{~N}, \mathrm{P}, \mathrm{K})$ yang tidak memiliki beda nyata dengan perlakuan $\mathrm{k} 2$ ( 75\% $\mathrm{N}, \mathrm{P}, \mathrm{K})$, namun $\mathrm{k} 1(100 \% \mathrm{~N}, \mathrm{P}, \mathrm{K})$ memiliki beda nyata dengan $\mathrm{k} 3(50 \% \mathrm{~N}, \mathrm{P}, \mathrm{K})$.

Pada tabel tersebut untuk diameter tongkol dapat dilihat bahwa pengaruh mandiri dosis pupuk hayati memiliki beda nyata pada tiap perlakuannya, h2 $(90 \mathrm{~kg} / \mathrm{ha})$ tidak memiliki bedanyata dengan perlakuan h1 (60kg/ha) dan h2 $(90 \mathrm{~kg} / \mathrm{ha})$ memiliki beda nyata dengan h3(120kg/ha). Pengaruh mandiri pupuk N, P, K tidak menunjukkan adanya perbedaan pada tiap perlakuannya terhadap diameter tongkol tanaman jagung.

Tongkol merupakan gudang penyimpanan tanaman jagung yang dapat digunakan untuk pembentukan biji, banyaknya biji dipengaruhi oleh panjang tongkol. Muhadzir, (1987) menyatakan bahwa unsur yang banyak berperan dalam pembentukan tongkol adalah unsur fosfor, bila kekurangan unsur ini menyebabkan pembentukan tongkol jagung menjadi tidak sempurna dengan 
ukuran tongkol yang kecil, baris biji tidak beraturan, dan biji yang kurang berisi. Selanjutnya Warisno, (1998) menyatakan bahwa pada saat pembentukan biji, senyawa fosfor yang tersimpan dalam daun dan batang tersimpan dalam bentuk biji, dan pada saat masak tiga per empat dari seluruh fosfor yang ada pada tanaman sudah tersimpan dalam biji.

Hasil pengamatan diameter dan panjang tongkol jagung ini diduga terjadi karena mikroba yang terdapat dalam pupuk hayati seperti Aspergillus niger sp., yang menguntungkan bagi tanaman untuk membantu ketersediaan $\mathrm{P}$ dalam tanah agar dapat dimanfaatkan oleh tanaman, mikroorganisme ini kurang bekerja secara optimal untuk melarutkan $\mathrm{P}$, sehingga kebutuhan unsur $\mathrm{P}$ bagi tanaman kurang terpenuhi.

Tabel 2. Pengaruh mandiri dosis pupuk hayati dan $\mathbf{N}, \mathbf{P}, \mathrm{K}$ terhadap jumlah baris biji per tongkol dan jumlah biji per tongkol

\begin{tabular}{lcc}
\hline \multicolumn{1}{c}{ Perlakuan } & $\begin{array}{c}\text { Jumlah } \\
\text { Baris Biji Per } \\
\text { Tongkol }\end{array}$ & $\begin{array}{c}\text { Jumlah } \\
\text { Biji Per } \\
\text { Tongkol }\end{array}$ \\
\hline Dosis Pupuk Hayati & $14,69 \mathrm{~b}$ & $414,82 \mathrm{ab}$ \\
h1 $(60 \mathrm{~kg} / \mathrm{ha})$ & $14,87 \mathrm{~b}$ & $437,93 \mathrm{~b}$ \\
h2 $(90 \mathrm{~kg} / \mathrm{ha})$ & $14,02 \mathrm{a}$ & $358,33 \mathrm{a}$ \\
h3 $(120 \mathrm{~kg} / \mathrm{ha})$ & & \\
Dosis Pupuk Kimia & $14,60 \mathrm{a}$ & $422,18 \mathrm{a}$ \\
k1 $(100 \% \mathrm{~N}, \mathrm{P}, \mathrm{K})$ & $14,62 \mathrm{a}$ & $409,96 \mathrm{a}$ \\
k2 $(75 \% \mathrm{~N}, \mathrm{P}, \mathrm{K})$ & $14,36 \mathrm{a}$ & $378,96 \mathrm{a}$ \\
k3 $(50 \% \mathrm{~N}, \mathrm{P}, \mathrm{K})$ &
\end{tabular}

Keterangan : Nilai rata-rata perlakuan yang ditandai dengan huruf yang sama pada kolom yang sama tidak berbeda nyata berdasarkan uji Jarak Berganda Duncan pada taraf nyata 5\%

Berdasarkan tabel 2 dapat dilihat bahwa efek mandiri dosis pupuk hayati menunjukkan bahwa perlakuan h1 (60kg/ha) dan h2 $(90 \mathrm{~kg} / \mathrm{ha})$ tidak berbeda nyata terhadap jumlah baris biji per tongkol, namun berbeda nyata dengan $\mathrm{h} 3$ $(120 \mathrm{~kg} / \mathrm{ha})$, sedangkan pengaruh efek mandiri dosis pupuk N, P, K pada tabel 2 memperlihatkan bahwa tiap perlakuan tidak memiliki beda yang nyata terhadap jumlah baris biji per tongkol.

Pada tabel 2 dapat dilihat bahwa efek mandiri dosis pupuk hayati terhadap jumlah biji memiliki perbedaan yang nyata pada perlakuannya. Perlakuan h2 $(90 \mathrm{~kg} / \mathrm{ha})$ tidak memiliki beda nyata dengan perlakuan $\mathrm{h} 1(60 \mathrm{~kg} / \mathrm{ha})$ dan memiliki beda nyata dengan perlakuan h3(120kg/ha), sedangkan efek mandiri dosis pupuk N, P, K pada tabel menunjukkan bahwa tidak terdapat perbedaan pada tiap taraf perlakuan terhadap jumlah biji tongkol.

Pada tabel tersebut dapat dilihat hasil analisis statistik menunjukkan bahwa jumlah baris dan jumlah biji per tongkol jagung pada taraf dosis pupuk $\mathrm{N}, \mathrm{P}, \mathrm{K}$ tidak menunjukkan adanya perbedaan yang nyata, sedangkan pada pupuk hayati perlakuan $\mathrm{h} 2(90 \mathrm{~kg} / \mathrm{ha})$ tidak memiliki beda yang nyata dengan $\mathrm{h} 1(60 \mathrm{~kg} / \mathrm{ha})$ untuk parameter pengamatan jumlah biji dan jumlah baris biji per tongkol. Hal ini diduga karena pupuk hayati yang mengandung mikroorganisme pelarut $\mathrm{P}$, yang salah satunya adalah Aspergillus niger sp., kurang optimal untuk melarutkan unsur hara fosfor dalam tanah, selain itu $\mathrm{P}$ yang tersedia dalam tanah juga tergolong rendah, yaitu $12,3 \mathrm{mg} / \mathrm{kg}$, sehingga dosis pupuk kimia yang diberikan tidak memberikan perbedaan pada tiap perlakuannya. Hal ini diduga disebabkan terjadi karena tanah yang tergolong masam, sehingga $\mathrm{P}$ terikat kuat dalam bentuk Al-P dan fe-P dan menyebabkan ketersediaannya dalam tanah kurang, sehingga ketersediaannya kurang untuk dapat dimanfaatkan tanaman.

Henry, (1994) menyatakan bahwa unsur P pada tanah dimanfaatkan tanaman dalam bentuk ion ortho fosfat primer dan ion ortho fosfat sekunder $\left(\mathrm{H}_{2} \mathrm{PO}_{4^{-}}\right.$atau $\mathrm{HPO}_{2}^{-}$. Proporsi penyerapan kedua ion ini dpengaruhi $\mathrm{pH}$ area perakaran tanaman. Unsur P ini terdapat di dalam substansi-substansi organis yang penting untuk tanaman, yaitu di dalam nucleo protein (inti protein), maka $P$ terdapat banyak sekali di dalam buah, biji, atau di dalam bagian-bagian muda tanaman.

Tabel 3. Pengaruh mandiri dosis pupuk hayati dan $N, P, K$ terhadap bobot biji pipilan kering per tanaman dan bobot 100 biji.

\begin{tabular}{|c|c|c|}
\hline Perlakuan & $\begin{array}{c}\text { Bobot Biji Pipilan } \\
\text { Kering Per } \\
\text { Tanaman }(g)\end{array}$ & $\begin{array}{c}\text { Bobot } 100 \\
\text { Biji }(\mathrm{g})\end{array}$ \\
\hline \multicolumn{3}{|l|}{ Dosis Pupuk Hayati } \\
\hline h1 (60 kg/ha) & $74,82 \mathrm{ab}$ & $20,31 \mathrm{a}$ \\
\hline h2 (90 kg/ha) & $83,25 \mathrm{~b}$ & $21,14 \mathrm{a}$ \\
\hline h3 (120 kg/ha) & $67,29 \mathrm{a}$ & $19,49 \mathrm{a}$ \\
\hline \multicolumn{3}{|l|}{ Dosis Pupuk Kimia } \\
\hline k1 (100\% N, P, K) & $81,50 \mathrm{~b}$ & $20,86 \mathrm{~b}$ \\
\hline k2 $(75 \% \mathrm{~N}, \mathrm{P}, \mathrm{K})$ & $77,12 \mathrm{~b}$ & $21,24 \mathrm{~b}$ \\
\hline k3 (50\% N, P, K) & $66,75 \mathrm{a}$ & $18,84 \mathrm{a}$ \\
\hline
\end{tabular}

Keterangan : Nilai rata-rata perlakuan yang ditandai dengan huruf yang sama pada kolom yang sama tidak berbeda nyata berdasarkan uji Jarak Berganda Duncan pada taraf nyata $5 \%$. 
Pada tabel 3, dapat dilihat bahwa pengaruh mandiri dosis pupuk hayati menunjukkan adanya perbedaan pada perlakuannya. Perlakuan h2 $(90 \mathrm{~kg} / \mathrm{ha})$ tidak memiliki beda nyata dengan taraf perlakuan $\mathrm{h} 1(60 \mathrm{~kg} / \mathrm{ha})$ terhadap bobot biji pipilan kering per tanaman, namun berbeda nyata dengan taraf perlakuan $\mathrm{h} 3$ $(120 \mathrm{~kg} / \mathrm{ha})$, sedangkan pengaruh mandiri perlakuan dosis pupuk $\mathrm{N}, \mathrm{P}, \mathrm{K}$ menunjukkan bahwa taraf perlakuan $\mathrm{k} 1(100 \% \mathrm{~N}, \mathrm{P}, \mathrm{K})$ dan $\mathrm{k} 2$ $(75 \% \mathrm{~N}, \mathrm{P}, \mathrm{K})$ tidak memiliki beda yang nyata terhadap bobot biji pipilan kering pertanaman, namun berbeda nyata dengan taraf perlakuan $\mathrm{k} 3$ (50\% N, P, K).

Pada tabel 3, dapat dilihat bahwa pengaruh mandiri dosis pupuk hayati tidak menunjukkan adanya perbedaan yang nyata pada taraf perlakuannya terhadap bobot 100 biji jagung, sedangkan pengaruh mandiri pupuk $\mathrm{N}, \mathrm{P}, \mathrm{K}$ menunjukkan tidak terdapat perbedaan untuk taraf perlakuan $\mathrm{k} 1(100 \% \mathrm{~N}, \mathrm{P}, \mathrm{K})$ dan $\mathrm{k} 2(75 \% \mathrm{~N}$, $\mathrm{P}, \mathrm{K})$ terhadap bobot 100 biji jagung, namun berbeda nyata dengan perlakuan $\mathrm{k} 3(50 \% \mathrm{~N}, \mathrm{P}$, $\mathrm{K})$.

Pada tabel tersebut hasil bobot biji jagung, nilai berat 100 biji masih rendah apabila dibandingkan dengan hasil konversi dari bobot biji 1000 butir jagung P-12 pada deksripsi, yang berhubungan dengan bobot biji pipilan kering pertanaman dan hasilnya juga rendah. Diduga unsur hara $\mathrm{P}$ ini kurang dapat terpenuhi, sehingga pengisian dan pemasakan biji yang mempengaruhi bobot biji menjadi kurang optimal, selaras dengan Aisyah, (2008) fosfor merupakan unsur kedua setelah nitrogen yang berperan bagi tanaman sebagai pemecah karbohidrat untuk energi penyimpanan ke seluruh bagian tanaman dalam bentuk ADP dan ATP, selain itu fosfor berperan juga dalam pembelahan sel melalui peranan nucleo protein yang ada dalam inti sel, meneruskan sifat kebaikan dari generasi ke generasi melalui peranan DNA, menentukan pertumbuhan akar, mempercepat kematangan dan berperan dalam produksi buah dan biji. Tanpa $\mathrm{P}$ proses dan peristiwa fisiologis tersebut tidak dapat berlangsung.

Tanaman jagung menyerap unsur $\mathrm{P}$ dalam bentuk ion mono fosfat $\left(\mathrm{H}_{2} \mathrm{PO}_{4}^{-}\right)$dan fosfat sekunder $\left(\mathrm{HPO}_{4}{ }^{-}\right)$. Penyebab kurang ketersediaannya fosfor dalam bentuk ion-ion $\mathrm{HPO}_{4}^{-}$dan $\mathrm{H}_{2} \mathrm{PO}_{4}^{-}$terjadi karena pupuk hayati yang diberikan kurang mampu bekerja secara optimal untuk melarutkan P yang dibutuhkan tanaman dalam tanah. Hal ini diduga karena $\mathrm{pH}$ tanah yang rendah dan bersifat masam sehingga $P$ terikat kuat dalam bentuk Al-P dan Fe-P, meskipun perlakuan $\mathrm{h} 2(90 \mathrm{~kg} / \mathrm{ha})$ signifikan dan memberikan pengaruh yang baik terhadap bobot biji, namun bobot biji masih rendah apabila dibandingkan dengan bobot biji pada deskripsi.

Bobot biji juga dipengaruhi oleh pembagian hasil asimilasi selama pengisian biji. Asimilat yang merupakan hasil dari fotosintesis yang disimpan dalam biji dipengaruhi oleh fotosintesis daun, fotosintesis bukan daun, dan remobilisasi hasil asimilasi yang disimpan dalam organ tanaman selain biji (Gardner, 1991). Rendahnya bobot biji diduga karena hasil asimilasi yang didistribusikan pada biji kurang dan lebih banyak pada batang tanaman. Menurut Goldswothy dan Fischer, (1992) apabila pertumbuhan biji hampir sempurna penyediaan asimilat dari fotosintesis yang terjadi dapat melebihi permintaan biji dan berat kering tertimbun kembali dalam batang dan bagian bagian vegetatif lainnya. Dapat dilihat pada tanaman yang memiliki tinggi tanaman yang optimal dan memiliki tinggi rata-rata melebihi deskripsi tinggi tanaman jagung P-12 itu sendiri. Sowell, (1961) dikutip Goldsworthy dan Fischer, (1992) menyatakan bahwa pertumbuhan vegetatif batang membatasi pertumbuhan tongkol awal. Menurut Fischer dkk., (1992) produksi bahan kering selama pembungaan adalah $20 \%$ lebih besar dalam tanaman yang pendek daripada tanaman yang tinggi.

Tabel 4. Pengaruh mandiri dosis pupuk hayati dan $N, P, K$ terhadap indeks panen tanaman jagung.

\begin{tabular}{lc}
\hline \multicolumn{1}{c}{ Perlakuan } & Indeks Panen \\
\hline Dosis Pupuk Hayati & \\
h1 $(60 \mathrm{~kg} / \mathrm{ha})$ & $0,45 \mathrm{~b}$ \\
h2 $(90 \mathrm{~kg} / \mathrm{ha})$ & $0,42 \mathrm{ab}$ \\
h3 $(120 \mathrm{~kg} / \mathrm{ha})$ & $0,38 \mathrm{a}$ \\
Dosis Pupuk Kimia & \\
k1 $(100 \% \mathrm{~N}, \mathrm{P}, \mathrm{K})$ & $0,43 \mathrm{a}$ \\
k2 $(75 \% \mathrm{~N}, \mathrm{P}, \mathrm{K})$ & $0,40 \mathrm{a}$ \\
k3 $(50 \% \mathrm{~N}, \mathrm{P}, \mathrm{K})$ & $0,41 \mathrm{a}$ \\
\hline
\end{tabular}

Keterangan : Nilai rata-rata perlakuan yang ditandai dengan huruf yang sama pada kolom yang sama tidak berbeda nyata berdasarkan uji Jarak Berganda Duncan pada taraf nyata 5\%

Pada tabel 4, dapat dilihat bahwa pengaruh mandiri perlakuan pupuk hayati memberikan 
perbedaan pada tiap perlakuannya, perlakuan $\mathrm{h} 1(60 \mathrm{~kg} / \mathrm{ha})$ tidak berbeda nyata dengan perlakuan $\mathrm{h} 2(90 \mathrm{~kg} / \mathrm{ha})$ untuk indeks panen jagung, namun berbeda nyata dengan perlakuan h3(120kg/ha), sedangkan pengaruh mandiri perlakuan pupuk $\mathrm{N}, \mathrm{P}, \mathrm{K}$ tidak memberikan beda nyata pada tiap perlakuannya.

Dua istilah yang berguna untuk menggambarkan pembagian berat kering oleh tanaman ialah hasil panen biologis dan hasil panen ekonomis. Istilah panen biologis menggambarkan penimbunan berat kering total untuk suatu sistem tanaman. Hasil panen pertanian digunakan untuk menyatakan berat organ-organ tanaman yang menyusun produk yang bernilai ekonomi, proporsi hasil panen biologis yang ditunjukan dalam bentuk hasil panen ekonomis disebut indeks panen, yang menunjukkan karakteristik adanya perpindahan berat kering ke bagian yang dipanen, (Gardner, 1991).

Indeks panen telah digunakan sebagai suatu ukuran yang mendasari seleksi untuk hasil yang tinggi, tetapi mempunyai batas-batas yang pasti. Nilai indeks panen dapat bervariasi dari 0,15 sampai 0,52 antar kultivar (Seetharaman, 1977 dikutip Goldsworthy dan Fischer, 1992) dan nilainya akan bergantung pada lama dan laju pertumbuhan relatif sebelum dan sesudah antesis dan pada pembagian berat kering setelah antesis (Goldsworthy dan Fischer, 1992).

\section{Kesimpulan}

1. Tidak terdapat interaksi antara dosis pupuk hayati dan pupuk $\mathrm{N}, \mathrm{P}, \mathrm{K}$ terhadap komponen hasil dan hasil tanaman jagung hibrida P-12 di dataran medium Jatinangor.

2. Pengaruh mandiri perlakuan dosis pupuk hayati pada taraf $90 \mathrm{~kg} / \mathrm{ha}$ rata-rata memberikan pengaruh terbaik terhadap komponen hasil dan hasil tanaman jagung, yaitu pada diameter tongkol, jumlah baris biji per tongkol, jumlah biji per tongkol, bobot biji pipilan kering per tanaman, dan indeks panen. Pengaruh mandiri dosis pupuk N,P,K memberikan pengaruh terbaik pada taraf $75 \%$ N,P,K terhadap komponen hasil dan hasil yaitu pada panjang tongkol, bobot 100 biji dan bobot biji pipilan kering per tanaman.

\section{Daftar Pustaka}

Adiningsih, Sri j., T. Prihatini, J.Purwani, and A. Kentjanasari. 1997. Development ofintergrated fertilizer management to sustain food crop production in Indonesia. The use of organic and biofertilizer. IARD Journal 19(4):153-172

Aiysah D. Suyono, Tien Kurniatin, Siti Mariam, Benny Joy, Maya Damayani, Tamyid Syammusa, Neni Nurlaeni, Anny Yuniarti, Emma Trinurani, Yuliati Machfud. 2008. Pupuk dan Pemupukan. UNPAD PRESS. Bandung

Anderson, 1979. Petunjuk Modern Kepada Kesehatan. Indonesia Publ. House.p. 42-45.

Gardner, F. P. Pearce, R. And B.Mitchel, R. L. 1991. Fisiologi Tanaman Budidaya. Diterjemahkan oleh Herawati Susilo. Penerbit Universitas Indonesia. Jakarta.

Gunawan Satari, Tati Nurmala, Oih Al Alis Mihardja, Aep Wawan Irwan, Agus Wahyudin. 2004. Dasar-Dasar Agronomi. Giratuna. Bandung.

Goldsworthy, P.R. dan N.M. Fisher. 1992. Fisiologi Tanaman Budidaya Tropik (terjemahan Tohari). Gajah Mada University Press. Yogyakarta.

Handayani, E., Didiek Indradewa, dan Joko Widodo. 1996. Analisis Pertumbuhan Tanaman Mentimun secara Hidroponik dengan Inokulasi Azotobacter dan Azospirillum pada Berbagai Takaran Nitrogen. Jurnal AgrUMY Vol. VI/1 Januari 1998. Faperta Universitas Muhammadiyah Yogyakarta

Kathan Muhadjir, 1998. Karakteristik Tanaman Jagung. Balai Tanaman Bogor.

Las, L., A.K. Makarim, H.M. Toha, dan A. Gani. 2002. Panduan Teknis Pengelolaan Tanaman dan Sumberdaya Terpadu Padi Sawah Irigasi. Badan Litbang Pertanian, Departemen Pertanian.

Mengel, K.L. and E.A. Krkby. 1984. Principles of Plant Nutrition. International Potash Institute. Switzerland.

Purwono dan Rudi Hartono. 2005. Bertanam Jagung Unggul. Penebar Swadaya. Jakarta.

Sarwono Hardjowigeno. 2003. Ilmu Tanah. Edisi Revisi. Akademika Presindo. Jakarta.

Subba Rao. 1982. Biofertilizer in agriculture. Oxfort-IBH, New Delhi.

Warisno. 1998. Budidaya Jagung Hibrida. Kanisus. Yogyakarta. 